\title{
Innate Immune Protection against Infectious Diseases by Pulmonary Administration of a Phospholipid-Conjugated TLR7 Ligand
}

\author{
Christina C.N. Wu ${ }^{a}$ Brian Crain ${ }^{a}$ Shiyin Yao ${ }^{a}$ Mojgan Sabet $^{b}$ \\ Fitzgerald S. Lao ${ }^{a}$ Rommel I. Tawatao ${ }^{a}$ Michael Chan ${ }^{a}$ Donald F. Smee \\ Justin G. Julander ${ }^{c}$ Howard B. Cottam $^{a}$ Donald G. Guiney ${ }^{b}$ Maripat Corr ${ }^{b}$ \\ Dennis A. Carson ${ }^{a}$ Tomoko Hayashi ${ }^{a}$ \\ ${ }^{a}$ Rebecca and John Moores UCSD Cancer Center and ${ }^{b}$ Department of Medicine, University of California San Diego, \\ La Jolla, Calif., and 'Institute for Antiviral Research, Utah State University, Logan, Utah, USA
}

\section{Key Words}

Anthrax · Immunotherapy $\cdot$ Influenza $\cdot$ Phospholipid conjugation · Toll-like receptor $7 \cdot$ Venezuelan equine encephalitis · Virus infection

\begin{abstract}
Pulmonary administration of Toll-like receptor (TLR) ligands protects hosts from inhaled pathogens. However, systemic side effects induced by TLR stimulation limit clinical development. Here, a small-molecule TLR7 ligand conjugated with phospholipid, 1V270 (also designated TMX201), was tested for innate immune activation and its ability to prevent pulmonary infection in mice. We hypothesized that phospholipid conjugation would increase internalization by immune cells and localize the compound in the lungs, thus avoiding side effects due to systemic cytokine release. Pulmonary 1V270 administration increased innate cytokines and chemokines in bronchial alveolar lavage fluids, but neither caused systemic induction of cytokines nor B cell proliferation in distant lymphoid organs. 1V270 activated pulmonary CD11c+ dendritic cells, which migrated to local lymph nodes. However, there was minimal cell infiltration into the pulmonary parenchyma. Prophylactic administra-
\end{abstract}

\section{KARGER}

(c) 2013 S. Karger AG, Basel

$1662-811 \mathrm{X} / 13 / 0063-0315 \$ 38.00 / 0$

E-Mail karger@karger.com

www.karger.com/jin tion of $1 \mathrm{~V} 270$ significantly protected mice from lethal infection with Bacillus anthracis, Venezuelan equine encephalitis virus and $\mathrm{H} 1 \mathrm{~N} 1$ influenza virus. The maximum tolerated dose of $1 \mathrm{~V} 270$ by pulmonary administration was 75 times the effective therapeutic dose. Therefore, pulmonary 1V270 treatment can protect the host from different infectious agents by stimulating local innate immune responses while exhibiting an excellent safety profile.

(c) 2013 S. Karger AG, Basel

\section{Introduction}

Pathogen-associated molecules are recognized as danger signals by pattern recognition receptors on innate immune cells that initiate host defense reactions. Among the pattern recognition receptors, Toll-like receptors (TLRs) play essential roles in protective responses against infectious diseases $[1,2]$. Bacterial infections initiate a broad range of TLR activation, including TLR2, TLR4, TLR5, and TLR9 $[2,3]$. Alternatively, virus particles activate the innate immune system via nucleotide receptors, including endosomal TLR3, TLR7, TLR8, or TLR9, and various cytoplasmic recognition molecules [4]. Triggering of 
TLRs activates multiple signaling pathways that are essential for the protection of host barrier tissues from external microbial attack.

The innate immune response of the respiratory tract is the first line of defense against aerosolized pathogens and may profoundly affect manifestation of the disease and outcome of many viral, bacterial, and fungal infections. Failure to develop an early, robust innate immune response may foster microbial colonization and infection in the airways and lung parenchyma. Prophylactic administration of ligands for TLR2, TLR3, TLR4, and TLR9 has been reported to reduce the severity of various pulmonary infections [5-16]. However, excess TLR activation can also induce severe local and systemic inflammatory reactions. Such safety concerns have impeded the clinical development of TLR ligands as immune protectants [17].

We previously reported that covalent conjugation of a modified adenine-based TLR7 agonist to mouse serum albumin enhanced its ability to stimulate innate immune responses while reducing drug-induced systemic cytokine release [18]. Mice pretreated with the TLR7 ligand-mouse serum albumin conjugate, which was delivered via the pulmonary route, and subsequently challenged with Bacillus anthracis spores or H1N1 influenza A virus showed a significant delay in mortality [19]. However, modified proteins may be immunogenic, particularly with repeated dosing, limiting utility to a single course of therapy. The lung is normally bathed in various phospholipids [20]. Therefore, we synthesized 1V270 (designated TMX201 by Telormedix, Bioggio, Switzerland) consisting of the same purinebased TLR7 agonist conjugated to a physiologic C-16 phospholipid [18]. When 1V270 was previously used as an adjuvant in a standard vaccination study, both T helper 1 and 2 antigen-specific immune responses were activated, without the induction of local and systemic inflammation [18].

In the experiments reported here, pulmonary administration of this phospholipid-modified TLR7 ligand activated local dendritic cells (DC) with resultant cytokine release into the bronchioalveolar lavage (BAL) fluids. In contrast, pulmonary administration of 1 V270 did not cause systemic cytokine release, weight loss, or B cell mitogenesis in the distant lymphoid organs. The local effects of pulmonary 1V270 in mice were sufficient to increase resistance to otherwise lethal infections with $B$. anthracis, Venezuelan equine encephalitis (VEE) virus, and H1N1 influenza virus in mice. These results suggest that $1 \mathrm{~V} 270$ is a potent inducer of innate immune responses in the lung with an appropriate safety profile. This drug may therefore be useful for the protection against infection by aerosolized viral and bacterial pathogens.

\section{Materials and Methods}

\section{Animals}

Female C57BL/6, A/J and BALB/c mice were purchased from the Jackson Laboratory (Bar Harbor, Mass., USA) and Charles River Laboratory (Wilmington, Mass., USA), respectively. TLR4-, TLR7-, and MyD88-deficient mice were a gift from Dr. S. Akira (Osaka University, Osaka, Japan) and bred onto the C57BL/6 background at the University of California, San Diego (UCSD). The studies described here were carried out in strict accordance with the recommendations in the Guide for the Care and Use of Laboratory Animals of the National Institutes of Health. All procedures used in this study were approved by the Institutional Animal Care and Use Committees of UCSD and Utah State University.

\section{Reagents}

Phosphate-buffered saline (PBS, pH 7.4), RPMI 1640 medium (Life Technologies, Grand Island, N.Y., USA) and DMEM (Life Technologies) were supplemented with $10 \%$ fetal bovine serum (Sigma, St. Louis, Mo., USA) and penicillin/streptomycin (Sigma). Phospholipid-conjugated TLR7 ligand, 1V270, was synthesized in our laboratory as previously described [18]. 1V270 was dissolved in DMSO (Sigma) as a $10-\mathrm{mM}$ stock solution and kept at $-20^{\circ} \mathrm{C}$ until use. As standard endotoxin LAL testing has a false-positive reaction to phospholipids, compounds and conjugates were tested for potency in Tlr4-/- and wild-type bone marrow cells and found to have equal potency, suggesting no contaminating endotoxin activity [18].

\section{Intranasal and Intratracheal Administration of 1 V270 and} Collection of BAL Fluids

Mice were anesthetized and intratracheally or intranasally administered with the indicated doses of 1V270 dispersed in $50 \mu \mathrm{l}$ PBS, which forms small (100-150 nm) liposomal particles. The same solution without the drug was used as a vehicle control. Preliminary experiments with vital dye showed that both intranasal and intratracheal delivery methods led to pulmonary dispersal of the drug solution. Six, 24, 48, and $72 \mathrm{~h}$ after administration, mice were sacrificed and the sera, BAL fluids, and lungs were collected as described previously [18]. Cytokine levels in the BAL fluids and sera were determined by Luminex bead assays (Life Technologies). Total BAL cell numbers were determined using a Guava personal cytometer (EMD Millipore, Billerica, Mass., USA). Differential cell counts were morphologically determined after Wright-Giemsa staining. Lungs were fixed, embedded, sectioned, and stained with hematoxylin-eosin by the UCSD Histology Shared Resource.

In vivo Labeling of DCs with Carboxyfluorescein Succinimidyl Ester and Flow-Cytometric Analysis

Carboxyfluorescein succinimidyl ester (CFSE) was dissolved at $25 \mathrm{mM}$ in DMSO and subsequently diluted to $8 \mathrm{mM}$ in PBS. CFSE (50 $\mu$ l i.n.) was administered to anesthetized mice as previously described [21]. Four to $5 \mathrm{~h}$ after the CFSE treatment, mice were intratracheally treated with $1 \mathrm{~V} 270$, as indicated above; $18 \mathrm{~h}$ after drug administration, mice were sacrificed and the cervical, mediastinal, mesenteric, and inguinal lymph nodes were collected. Lymph node cells were stained for CD11c or B220 to identify DCs and B lymphocytes, respectively. The CFSE-positive cells in the $\mathrm{CD} 11 \mathrm{c}+$ population and the $\mathrm{B} 220+$ population were enumerated 
using a FACSCanto flow cytometer (BD Bioscience, San Jose, Calif., USA) and analyzed using FlowJo software (Tree Star, Ashland, Oreg., USA).

Efficacy Evaluation of 1V270 in Infectious Challenge Models

Three infection models were used to evaluate the immunoprotective efficacy of pulmonary $1 \mathrm{~V} 270$ treatment. The viral infection models, utilizing H1N1 influenza and VEE virus, were performed at the Institute for Antiviral Research (Utah State University). The studies using $B$. anthracis were performed at UCSD.

(1) Anthrax Model. Live spores from the Sterne strain of B. anthracis (pXO1+pXO2-) were prepared as previously described [19, 22]. A/J mice were given $1 \mathrm{nmol} 1 \mathrm{~V} 270$ i.n. or vehicle at 2 -week intervals by the intranasal route for three times. Four weeks after the last dose, mice were infected intranasally with $4 \times 10^{6} \mathrm{CFU}$ of live, heat-activated spores, and survival was monitored daily for 30 days. In separate experiments, A/J mice were treated with $1 \mathrm{~V} 270$ $(1 \mathrm{nmol})$ with or without irradiated $B$. anthracis spores $\left(5 \times 10^{7} /\right.$ mouse) on days 0,14 , and 28 , and BAL fluids were collected on day 35 . Irradiated spores were prepared as described previously [23]. Total serum IgA was measured with an ELISA kit (Bethyl Laboratories, Inc., Montgomery, Tex., USA).

(2) VEE Model. Female BALB/c mice were treated with $1 \mathrm{nmol}$ $1 \mathrm{~V} 270$ i.n. in $20 \mu \mathrm{l}$ saline on days -3 and -1 under anesthesia (ketamine/xylazine, $50 / 5 \mathrm{mg} / \mathrm{kg}$ i.p.). The Trinidad donkey strain of VEE virus (strain NR-332) was obtained from BEI Resources (Manassas, Va., USA) and prepared in Vero cells as previously described [24]. On day 0, VEE $0.1 \mathrm{ml}$ of a $50 \%$ cell culture infectious dose $\left(\mathrm{CCID}_{50}\right) / \mathrm{ml}$ was injected subcutaneously to each mouse as previously described $[25,26]$.

(3) Influenza Model. Female BALB/c mice were treated with $1 \mathrm{nmol} 1 \mathrm{~V} 270 \mathrm{i}$.n. in $20 \mu \mathrm{l}$ saline on days -3 and -1 under anesthesia (ketamine/xylazine, $50 / 5 \mathrm{mg} / \mathrm{kg}$ i.p.). Mouse-adapted influenza A/California/04/2009 (H1N1) was kindly provided by Dr. Elena Govorkova (St. Jude Children's Research Hospital, Memphis, Tenn., USA) [26]. On day $0,90 \mu \mathrm{l}$ of a $10^{4} \mathrm{CCID}_{50} /$ mouse of influenza was administered intranasally to anesthetized mice [24].

\section{Statistics}

Data are presented as means \pm SEM or SD, as indicated. Student's t test was used to compare two groups. One-way ANOVA or the Mantel-Cox log-rank test was used for multiple group comparisons. Kaplan-Meier survival curves and log-rank (MantelCox) tests were performed for survival studies. GraphPad Prism software (version 5.0b; GraphPad, San Diego, Calif., USA) was used for analysis. A value of $\mathrm{p}<0.05$ was considered to be statistically significant.

\section{Results}

Pulmonary Administration of 1V270 Activates Local

Innate Immune Responses without Induction of

Systemic Immune Responses

To characterize innate immune responses induced by pulmonary administration of $1 \mathrm{~V} 270$, cytokines and chemokines in BAL fluids were monitored for up to $72 \mathrm{~h}$ af- ter drug delivery. Interleukin (IL)-6, monocyte chemoattractant protein-1 (MCP-1), keratinocyte chemo-attractant (KC), and interferon (IFN)- $\gamma$-induced protein 10 (IP-10) were measured in BAL fluids (fig. 1). IP-10 was used as a surrogate marker of type 1 IFN induction [27]. IL-6, MCP-1, and KC significantly increased in the drugtreated animals by $6 \mathrm{~h}$ (fig. $1 \mathrm{a}-\mathrm{c})$. IP-10 induction peaked at $24 \mathrm{~h}$ and declined to baseline levels by $72 \mathrm{~h}$ after treatment (fig. 1d).

To assess the effect of $1 \mathrm{~V} 270$ on DC activation and migration, we monitored accumulation of CFSE-labeled $\mathrm{CD} 11 \mathrm{c}+$ cells in the draining mediastinal lymph nodes $24 \mathrm{~h}$ after drug administration (fig. 1e). The pulmonary 1V270 treatment significantly enhanced CD11c+ DC migration to the mediastinal lymph nodes but not to more distant lymphoid organs (fig. 1e).

The principal adverse effect of systemic TLR7 ligand administration is a 'cytokine syndrome' attributable to tumor necrosis factor (TNF)- $\alpha$ and related inflammatory mediators [28]. Hence, we compared the levels of TNFa and other proinflammatory cytokines in BAL fluid and sera $24 \mathrm{~h}$ after pulmonary administration of 1 V270. Notably, pulmonary $1 \mathrm{~V} 270$ treatment elicited only a minimal insignificant increase in TNFa and IL-6 in sera after a 4 -nmol dose, which is 4 times the effective drug concentration for pulmonary protection (fig. 1f, g).

One of the significant adverse effects associated with the FDA-approved small-molecule TLR7 ligand, imiquimod, is lymphocytosis/plasmacytosis due to TLR7 activation of B cells [29]. To study the potential influence of pulmonary 1V270 on lymphoid organs, the B cell numbers in the cervical, mediastinal, mesenteric, and inguinal lymph nodes were compared (fig. 2). 1 V270 treatment did not significantly increase B cell numbers in the draining mediastinal lymph nodes (fig. 2a) nor in the cervical, mesenteric, and inguinal nodes (fig. 2b-d).

\section{Pulmonary 1V270 Treatment Causes Minimal} Inflammation of the Lung Parenchyma and No Other Discernible Adverse Effects

To evaluate whether local induction of proinflammatory cytokines and chemokines by 1V270 could cause pulmonary edema or interstitial inflammation, histological changes in the lung were evaluated 6 and $24 \mathrm{~h}$ after treatment. At both time points, 1V270-treated lung sections did not show inflammatory cell infiltration into the lung parenchyma (fig. 3a).

We previously reported that high doses of an unconjugated TLR7 agonist caused anorexic behavior after both 


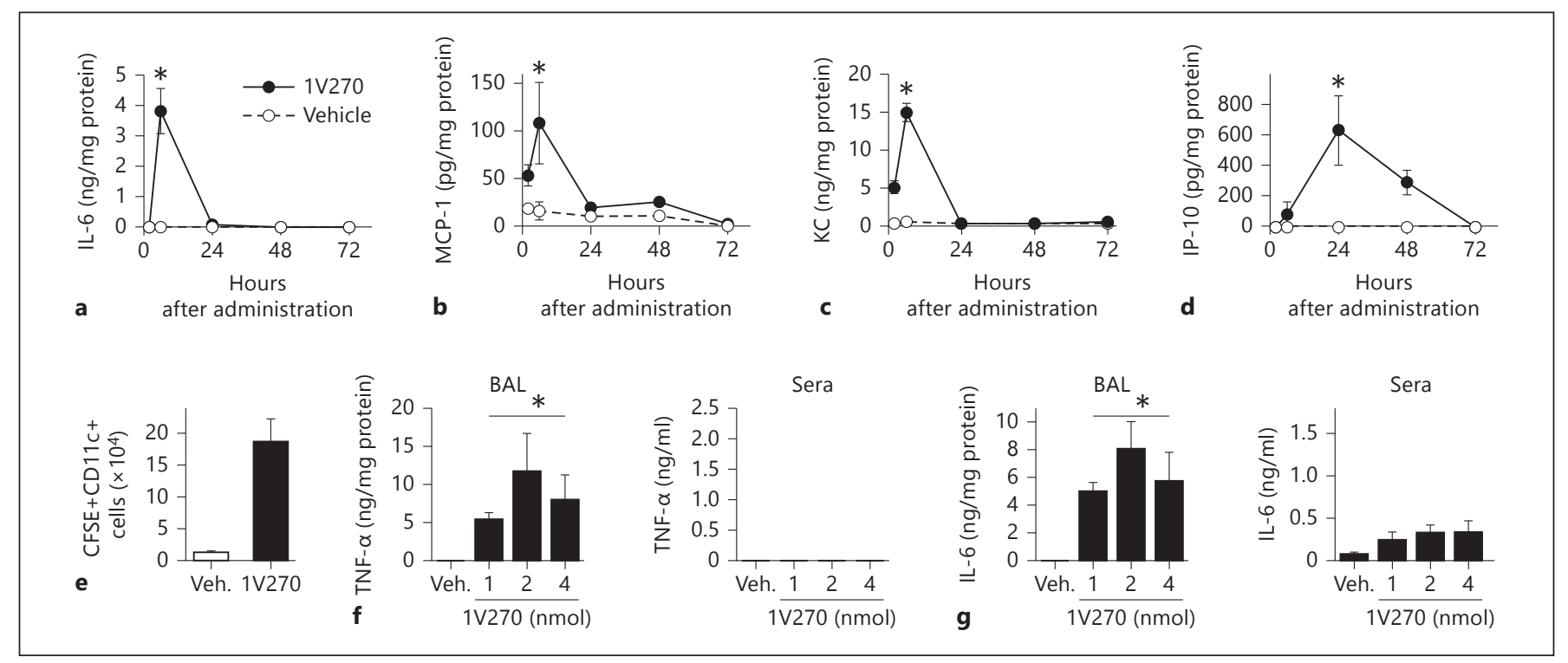

Fig. 1. Pulmonary administration of 1 V270 induces local innate immune activation. C57BL/ 6 mice ( $\mathrm{n}=5$ /group) were treated with $1 \mathrm{nmol} 1 \mathrm{~V} 270$ i.t. and BAL fluids were harvested 6, 24, 48, and $72 \mathrm{~h}$ after administration. IL-6 (a), MCP-1 (b), KC (c), and IP-10 (d) were measured in BAL fluids by Luminex beads assay. Data shown are means \pm SEM. The data are representative of 2 independent experiments. ${ }^{*} \mathrm{p}<0.05$ vs. vehicle-treated mice by one-way ANOVA with Dunnett's post hoc testing. e C57BL/6 mice ( $\mathrm{n}=$ 2-3/group) were intranasally inoculated with CFSE. Mice were then intrantracheally administered $1 \mathrm{nmol} 1 \mathrm{~V} 270$ or vehicle and mediastinal lymph nodes were collected $24 \mathrm{~h}$ after treatment. CFSE+CD11c+ cells were enumerated by flow cytometry. Data are means \pm SD of 2 independent experiments. ${ }^{*} \mathrm{p}<0.05$ by Student's $\mathrm{t}$ test. $\mathbf{f}, \mathbf{g}$ Mice $(\mathrm{n}=4)$ were intranasally administered 1,2 , and $4 \mathrm{nmol} 1 \mathrm{~V} 270$ or vehicle control, and BAL and sera were collected $24 \mathrm{~h}$ after treatment. TNFa (f) and IL-6 (g) were determined in BAL fluids and sera by Luminex beads assay. ${ }^{*} \mathrm{p}<0.05$ vs. vehicletreated mice by one-way ANOVA with Dunnett's post hoc testing.

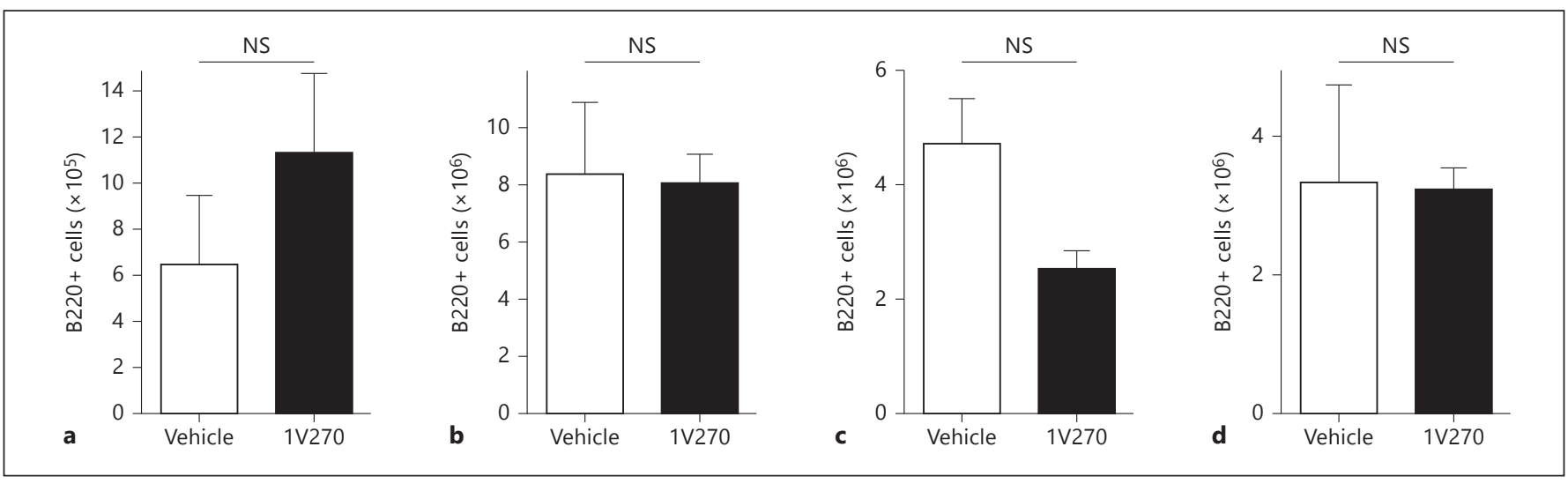

Fig. 2. Pulmonary administration of 1 V270 does not increase the B cell population. Mice were administered $1 \mathrm{nmol} 1 \mathrm{~V} 270$ i.t. Mediastinal (a), cervical (b), mesentric (c), and inguinal lymph nodes (d) were harvested 7 days after treatment. B cells were identified as a B220+ population by flow cytometry. NS = Not significant. intraperitoneal and pulmonary administration [30]. In contrast, the effective dose ( $1 \mathrm{nmol})$ of the phospholipidconjugated TLR7 agonist did not cause significant weight loss compared to vehicle-treated mice (fig. 3b). Indeed, significant anorexia was only seen at the maximum toler- ated dose of $75 \mathrm{nmol} / \mathrm{animal}$. This effect was entirely TLR7 dependent since TLR7 null mice did not lose weight after 1V270 treatment. Thus, 1V270 did not apparently have off-target toxic effects at dosages that induced immune responses in the lung. 
Fig. 3. Pulmonary 1 V270 treatment induces minimal cell infiltration into lung parenchyma and has negligible adverse effects. a C57BL/6 mice $(\mathrm{n}=5)$ were administered with $1 \mathrm{nmol} 1 \mathrm{~V} 270$ i.t. Lungs were harvested 6 and $24 \mathrm{~h}$ after treatment. Fixed sections were stained with HE (original magnification $\times 200)$. Scale bar $=200 \mu \mathrm{m}$. The sections are representative of 5 mice/group. b Mice were intratracheally treated with $1 \mathrm{nmol} 1 \mathrm{~V} 270$ or vehicle. c Wild-type or Tlr7-/- mice ( $\mathrm{n}=3-4$ /group) were administered $75 \mathrm{nmol} 1 \mathrm{~V} 270$ i.t. Body weights were monitored daily. ${ }^{*} \mathrm{p}<0.05$ vs. vehicletreated mice by one-way ANOVA with Dunnett's post hoc testing. WT $=$ Wild type.

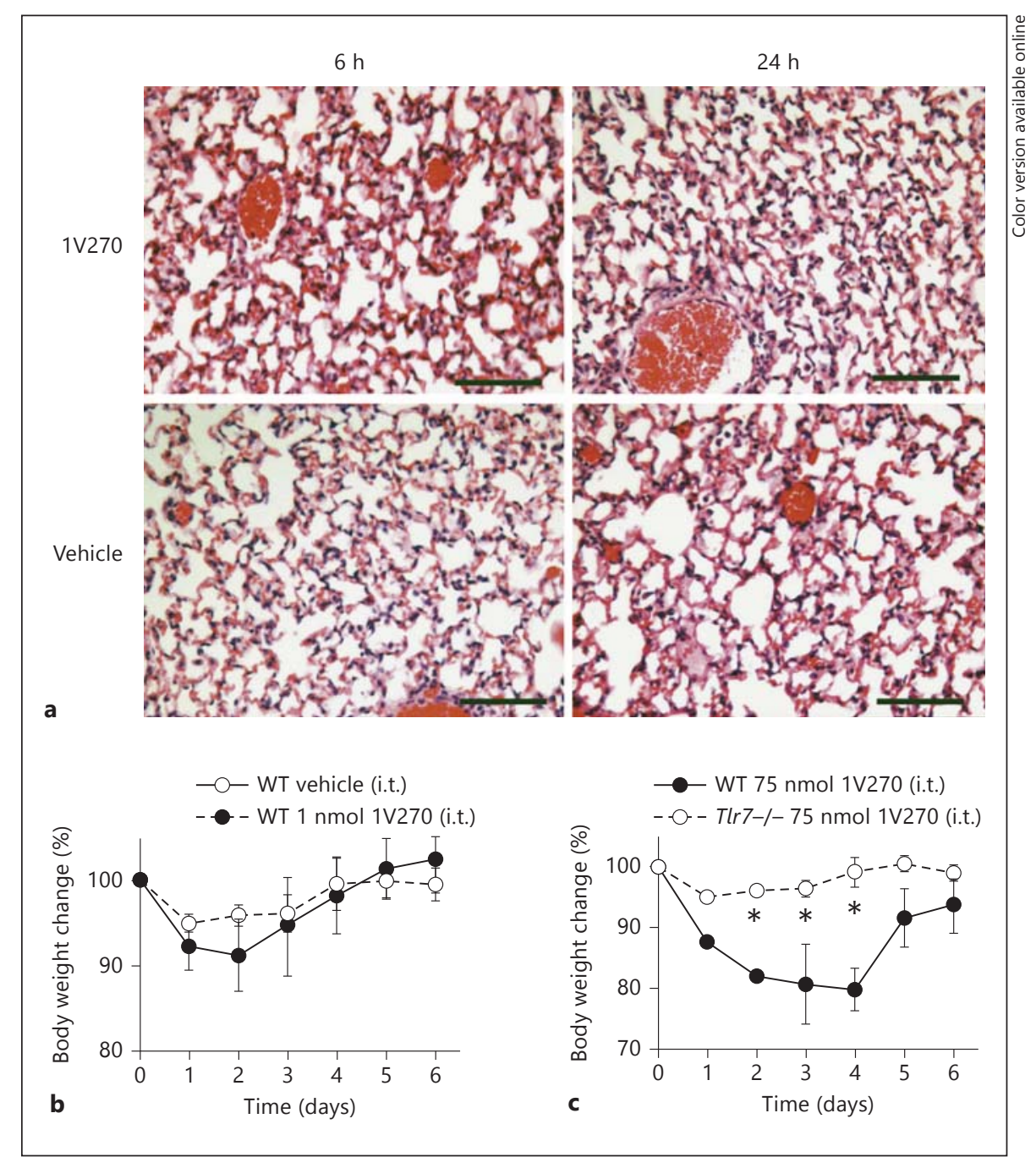

Pulmonary Administration of 1 V270 Promotes

Transient Neutrophil Infiltration in BAL Fluids in a

TLR7/MyD88-Dependent Manner

To further characterize the local innate immune response induced by pulmonary administration of $1 \mathrm{~V} 270$, the cellular composition of the BAL fluids was monitored for $72 \mathrm{~h}$ after administration of $1 \mathrm{nmol}$ drug (fig. 4). Total cell numbers in the BAL fluids increased over $48 \mathrm{~h}$ and declined to near baseline levels $72 \mathrm{~h}$ after administration (fig. 4a). A significant increase was observed in the neutrophil population 24 and $48 \mathrm{~h}$ after treatment (fig. $4 \mathrm{~b}$ ), whereas mononuclear cells were slightly elevated in both 1V270- and vehicle-treated mice $24 \mathrm{~h}$ after treatment (fig. 4c). The neutrophil influx at $24 \mathrm{~h}$ was dose responsive between 0.1 and $10 \mathrm{nmol} 1 \mathrm{~V} 270$ (fig. 4d, e).

To confirm that the transient neutrophil accumulation induced by pulmonary administration of 1V270 is TLR7-
MyD88 signaling pathway dependent, MyD88 or TLR7 null mice were also treated (fig. $4 \mathrm{f}, \mathrm{g}$ ). Neutrophil recruitment to BAL fluids was diminished in the two deficient strains (fig. 4f, g).

\section{Pulmonary Treatment with 1V270 Protects Mice from Infection}

To evaluate the ability of pulmonary $1 \mathrm{~V} 270$ to protect mice from diverse pathogens, we studied selected NIAID Biodefense Category A, B, and C Priority Pathogens: $B$. anthracis, VEE and inhalation H1N1 influenza [31]. To test the efficacy of pulmonary 1V270 treatment in a model of inhalation anthrax, A/J mice were dosed with $1 \mathrm{nmol}$ 1V270 three times at 2-week intervals. Four weeks after the last dose, the drug- or vehicle-treated mice were challenged with live $B$. anthracis spores. Survival was monitored for 30 days. Forty percent of the mice treated with 


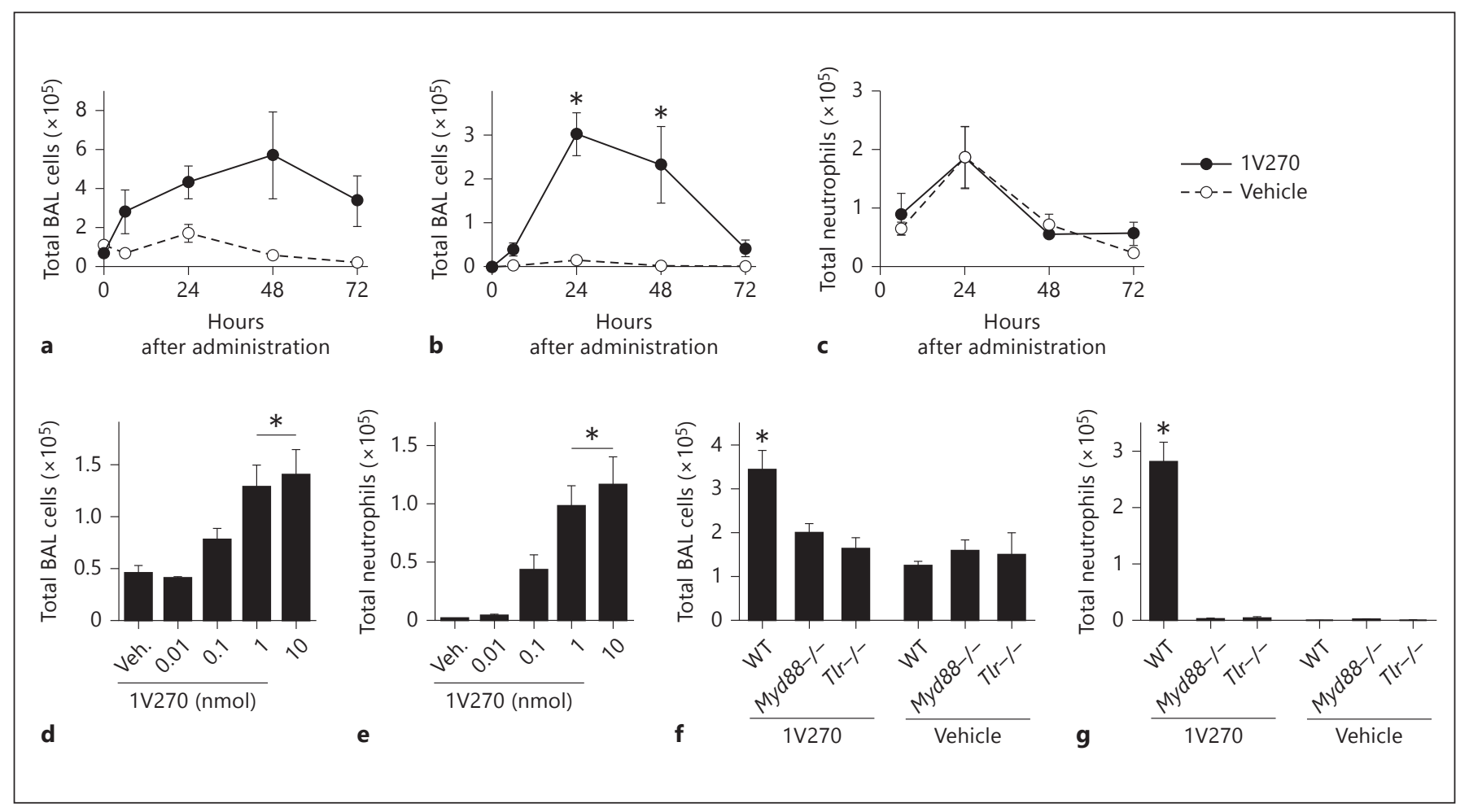

Fig. 4. Pulmonary administration of 1 V270 promotes neutrophil infiltration in BAL in a TLR7- and MyD88-dependent manner. C57BL/6 mice ( $\mathrm{n}=5$ /group) were administered $1 \mathrm{nmol} 1 \mathrm{~V} 270$ i.t. and BAL fluids were harvested $6,24,48$, and 72 h later. Total cell numbers (a) were determined using a Guava cytometer. Numbers of neutrophils (b) and mononuclear cells (c) in BAL fluids were identified after Wright-Giemsa staining. d, e Mice ( $n=5$ /group) were intratracheally treated with the indicated doses of 1V270 and BAL flu- ids were harvested $24 \mathrm{~h}$ after treatment. Numbers of total cells (d) and neutrophils (e) were determined as described above. f, $\mathbf{g}$ Wildtype (WT), Myd88-/- or Tlr7-/- mice (n = 5/group) were treated with $1 \mathrm{nmol} 1 \mathrm{~V} 270$ i.t. and BAL fluids were harvested $24 \mathrm{~h}$ after treatment. Numbers of total cells (f) and neutrophils ( $(\mathbf{g})$ were determined as described above. Data shown are means \pm SEM. The data are representative of 2 independent experiments. ${ }^{*} \mathrm{p}<0.05$ vs. vehicletreated mice by one-way ANOVA with Dunnett's post hoc testing.
1V270 survived at least 30 days, while control mice were all dead by day 7 ( $\mathrm{p}<0.01$, fig. $5 \mathrm{a}$ ). When A/J mice were intranasally treated with 1 V270 or with 1 V270 plus irradiated anthrax spores on days 0,14 , and 28 , total IgA levels in sera were significantly higher in mice treated with 1V270 $(299 \pm 20 \mathrm{ng} / \mathrm{ml})$ and 1V270 plus irradiated anthrax spores $(354 \pm 33 \mathrm{ng} / \mathrm{ml})$ compared to naïve mice $(117 \pm 9 \mathrm{ng} / \mathrm{ml})$.

In the VEE infection model, the virus infects through the subcutaneous route and disperses in the lungs, blood, and spleen prior to entering the central nervous system through the nasal olfactory nerves $[32,33]$. In this situation, innate immune stimulation in the nasal and respiratory tissues might prevent lethal encephalitis. To test this hypothesis, BALB/c mice were treated with pulmonary $1 \mathrm{~V} 270$ on days -3 and -1 before challenge with VEE virus subcutaneously. Eighty percent of 1V270-treated mice were protected from encephalitis while all control mice died by 12 days after infection (fig. 5b; $\mathrm{p}<0.0005$ ).

Using the same prophylactic protocol, 1V270 protected $100 \%$ of mice from lethal H1N1 pulmonary influenza infection (fig. $5 c, p<0.0001$ ).

\section{Discussion}

The pulmonary route of infection is of particular relevance in terms of bioterrorism since it is a quick way to disperse an infectious agent to a susceptible population. In this study, we have demonstrated that pulmonary delivery of a phospholipid-conjugated TLR7 ligand, 1V270, activated local innate immune responses without causing a systemic cytokine syndrome and without damaging pulmonary parenchymal tissue. This treatment completely prevented lethal pulmonary infection by influenza 


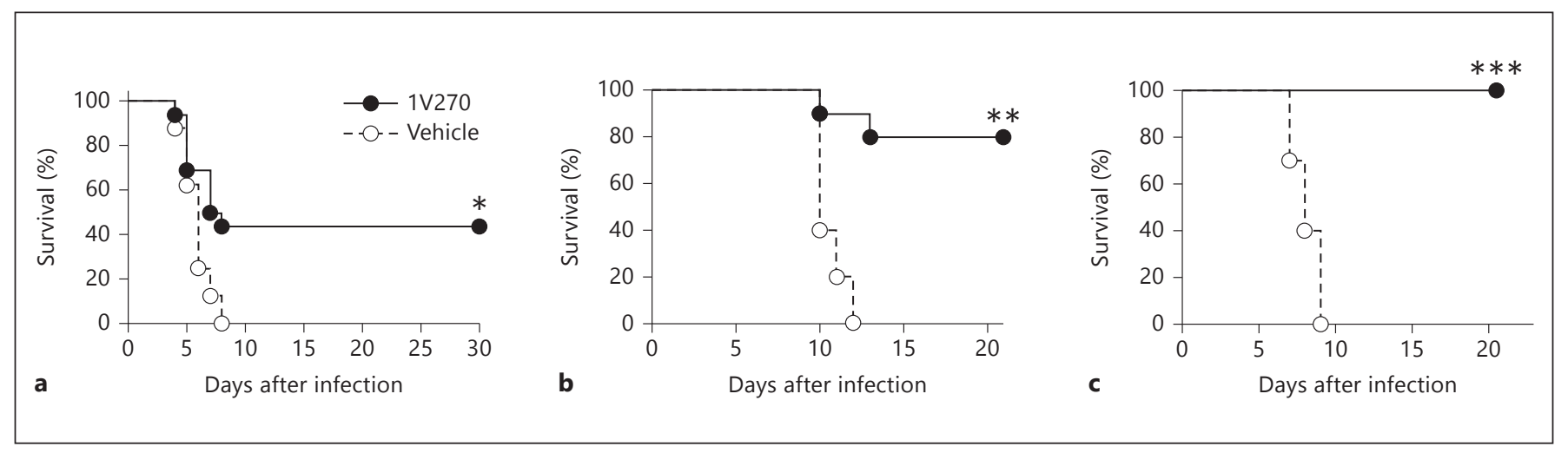

Fig. 5. Pulmonary treatment with $1 \mathrm{~V} 270$ protects mice from bacterial and viral infections. a $A / J$ mice $(n=16)$ were treated with 1V270 (1 nmol i.n.) or vehicle at 2-week intervals for three times and challenged with heat-activated live $B$. anthracis spores 4 weeks after the last immunization. Animal survival was monitored daily for up to 30 days. Kaplan-Meier survival curves and log-rank (Mantel-Cox) tests were performed to determine significance. The data were pooled from 2 independent experiments. b $1 \mathrm{~V} 270$ $(1 \mathrm{nmol} /$ mouse i.n.) was administered to BALB/c mice $(\mathrm{n}=20$ in the placebo group; $\mathrm{n}=10$ in the drug group) once a day on days -3 and -1 relative to virus exposure. Mice were challenged subcutaneously with VEE virus (Trinidad donkey, NR-332) on day 0. c $1 \mathrm{~V} 270$ ( $1 \mathrm{nmol} /$ mouse $)$ or placebo were administered intranasally to $\mathrm{BALB} / \mathrm{c}$ mice $(\mathrm{n}=20$ in placebo group; $\mathrm{n}=10$ in other groups) once a day on days -3 and -1 prior to virus exposure. Mice were challenged intranasally with an influenza A/California/04/2009 (H1N1) virus on day $0 .{ }^{*} \mathrm{p}<0.01,{ }^{* *} \mathrm{p}<0.0005$, and ${ }^{* * *} \mathrm{p}<0.0001$ vs. the vehicle-treated group by log-rank (Mantel-Cox) test. virus and protected $40 \%$ of exposed animals from inhaled anthrax. This treatment was also $80 \%$ effective in the prevention of death from VEE virus infection.

A focus of our study was the safety profile of pulmonary 1V270 treatment. Prophylactic administration of ligands for TLR2, TLR3, TLR4, and TLR9 has been reported to reduce the severity of pulmonary influenza infection $[5,7,8,10,11,14,15]$. In spite of the efficacy of the TLR activators, these drugs have raised safety concerns that have impeded their clinical development [17]. Among TLR ligands, imiquimod is an FDA-approved TLR7 agonist for the topical treatment of papilloma virus infections [34]. However, imiquimod can cause systemic cytokine release and also exhibits significant off-target effects that are independent of TLR7 and TLR8 activation [35]. The current study shows that 1V270, a phospholipid-conjugated TLR7 ligand, provides several safety advantages compared to most other TLR agonists. First, pharmacodynamic data indicate that immune activation by pulmonary-administered $1 \mathrm{~V} 270$ is confined to the respiratory tract. Effective doses of the drug did not significantly increase cytokine levels in the blood and did not cause anorexia. Second, pulmonary 1 V270 did not induce B cell proliferation in secondary lymphoid organs. Third, the cytokine induction and cell infiltration in BAL induced by 1 V270 was transient and not associated with lung interstitial inflammation. The maximum tolerated dose of 1 V270 adminis- tered by the pulmonary route was $75 \mathrm{nmol} / \mathrm{animal}$, which is 75 times higher than the effective dose of $1 \mathrm{nmol} /$ animal. Moreover, the body weight loss induced by the maximum tolerated dose was entirely TLR7 dependent and was not attributable to off-target toxicity [30]. In humans, TLR7 expression is primarily limited to plasmacytoid DCs and to activated B cells under normal conditions. Several TLRs (e.g. TLR2, TLR3, TLR4, TLR5, and TLR6) are expressed in a broader range of cell types $[36,37]$. The relatively limited expression pattern of TLR7 may prevent excessive immune stimulation by pulmonary administration. The inhalation of TLR9 activators has been reported to be safe in humans at doses that stimulate innate immune responses [38]. Taken together, our data indicate that 1V270, given by the pulmonary route, should also display an excellent safety profile in humans.

Another aim of this study was to determine the efficacy of pulmonary 1V270 treatment as an immune protectant against a range of infectious pathogens. Pulmonary treatment with the drug broadly activated local innate immune responses, inducing both neutrophil recruitment and IP-10 release, a surrogate marker of type 1 IFN production, in the BAL fluids. Local or systemic administration of exogenous type 1 IFN augments immune defenses against RNA viruses, but it is not entirely protective against influenza [39-44]. Additional responses to stimuli that induce endogenous IFN production 
have been suggested to have an added beneficial effect to host responses in influenza infection $[45,46]$. A recent report indicated that neutrophils also play a protective role in severe influenza infection in mice [47]. Consistent with its effects relative to both IFN and neutrophils, pulmonary $1 \mathrm{~V} 270$ treatment protected $100 \%$ of mice from lethal H1N1 influenza infection.

The 1V270 treatment also protected mice from pulmonary infection by inhaled $B$. anthracis spores, confirming earlier results with an albumin-conjugated TLR7 ligand [48]. In part, the induction of type 1 IFN may be involved in the protection from anthrax because intranasal administration of the type 1 IFN inducer, TLR3 ligand, poly-ICLC, a strong type 1 IFN inducer, was also reported to protect animals from inhaled anthrax [48]. However, the 1V270 treatment also caused activation of pulmonary DCs that migrated to the regional lymph nodes. It seems likely that the persistent immune protection induced by 1 V270 may be due to effects on activated DCs that orchestrate innate and adaptive immune responses. TLR7 ligands have also been shown to increase the viability of macrophages infected with $B$. anthracis [24]. We also demonstrated that $1 \mathrm{~V} 270$ administration increased serum IgA levels, suggesting that $1 \mathrm{~V} 270$ can enhance local mucosal immune protection $[49,50]$.

To test the efficacy of pulmonary 1V270 treatment in a model utilizing a route other than airway challenge, we studied VEE virus infection. Because natural infection by the VEE virus is mediated by mosquito bites, the subcutaneous challenge model has been well characterized in mice $[51,52]$. In this model, virus replication in the draining lymph node is detectable within $3 \mathrm{~h}$ and the peak of viremia is observed at $12 \mathrm{~h}$. Then, the virus replicates in the nasal epithelium and enters the central nervous system through sensory olfactory neurons. Death ensues 7-10 days after infection [52-57]. Although systemic type 1 IFN shows protective effects on subcutaneous infection by VEE virus, pulmonary $1 \mathrm{~V} 270$ did not induce systemic cytokines. However, it is very likely that intranasal treatment with the drug induced local innate immune responses in the nasal passages, which inhibited the entry of the virus into the olfactory neuroepithelium and the brain.

In conclusion, this study showed that pulmonary administration of a phospholipid-conjugated TLR7 agonist, $1 V 270$, activated local innate immune responses and provided protection from three infectious diseases. Pulmonary 1 V270 treatment did neither induce systemic cytokine release nor B cell proliferation. Prophylactic administration of $1 \mathrm{~V} 270$ could be a potential biodefense agent to increase innate host resistance to pulmonary pathogens with minimal side effects.

\section{Acknowledgment}

We thank Sharon Okamoto, Tyler Workinger, Christine Gray, Linda Vuong, Michael Rosenbach, and Lisa Way for technical assistance.

This work was supported by the National Institutes of Health (grant Nos. AI077989 and AR062236, and contract No. 272200900034C).

\section{Conflicts of Interest}

Dennis Carson is a scientific advisory board member of Telormedix that has licensed 1V270.

\section{References}

1 Williams AE, Edwards L, Humphreys IR, Snelgrove R, Rae A, Rappuoli R, Hussell T: Innate imprinting by the modified heat-labile toxin of Escherichia coli (LTK63) provides generic protection against lung infectious disease. J Immunol 2004;173:7435-7443.

2 O'Neill LA, Golenbock D, Bowie AG: The history of Toll-like receptors - redefining innate immunity. Nat Rev Immunol 2013;13:453460.

3 Kawai T, Akira S: Toll-like receptors and their crosstalk with other innate receptors in infection and immunity. Immunity 2011;34:637650 .

4 Gürtler C, Bowie AG: Innate immune detection of microbial nucleic acids. Trends Microbiol 2013;21:413-420.
5 Hammerbeck DM, Burleson GR, Schuller CJ, Vasilakos JP, Tomai M, Egging E, Cochran FR, Woulfe S, Miller RL: Administration of a dual toll-like receptor 7 and toll-like receptor 8 agonist protects against influenza in rats. Antiviral Res 2007;73:1-11.

6 Hutchens MA, Luker KE, Sonstein J, Nunez G, Curtis JL, Luker GD: Protective effect of Toll-like receptor 4 in pulmonary vaccinia infection. PLoS Pathog 2008;4:e1000153.

7 Wong JP, Christopher ME, Viswanathan S, Karpoff N, Dai X, Das D, Sun LQ, Wang M, Salazar AM: Activation of toll-like receptor signaling pathway for protection against influenza virus infection. Vaccine 2009;27:3481-3483.

-8 Abdul-Careem MF, Firoz Mian M, Gillgrass AE, Chenoweth MJ, Barra NG, Chan T, Al-
Garawi AA, Chew MV, Yue G, van Roojen N, Xing Z, Ashkar AA: FimH, a TLR4 ligand, induces innate antiviral responses in the lung leading to protection against lethal influenza infection in mice. Antiviral Res 2011;92:346355.

9 Nasirudeen AM, Wong HH, Thien P, Xu S, Lam KP, Liu DX: RIG-I, MDA5 and TLR3 synergistically play an important role in restriction of dengue virus infection. PLoS Negl Trop Dis 2011;5:e926.

10 Shinya K, Okamura T, Sueta S, Kasai N, Tanaka M, Ginting TE, Makino A, Eisfeld AJ, Kawaoka Y: Toll-like receptor pre-stimulation protects mice against lethal infection with highly pathogenic influenza viruses. Virol J 2011;8:97. 
-11 Shinya K, Ito M, Makino A, Tanaka M, Miyake K, Eisfeld AJ, Kawaoka Y: The TLR4TRIF pathway protects against H5N1 influenza virus infection. J Virol 2012;86:19-24.

$\checkmark 12$ Beckett EL, Phipps S, Starkey MR, Horvat JC, Beagley KW, Foster PS, Hansbro PM: TLR2, but not TLR4, is required for effective host defence against Chlamydia respiratory tract infection in early life. PLoS One 2012; 7:e39460.

13 St Paul M, Mallick AI, Read LR, Villanueva AI, Parvizi P, Abdul-Careem MF, Nagy E, Sharif S: Prophylactic treatment with Tolllike receptor ligands enhances host immunity to avian influenza virus in chickens. Vaccine 2012;30:4524-4531.

-14 Tuvim MJ, Gilbert BE, Dickey BF, Evans SE: Synergistic TLR2/6 and TLR9 activation protects mice against lethal influenza pneumonia. PLoS One 2012;7:e30596.

$\checkmark 15$ Tan AC, Mifsud EJ, Zeng W, Edenborough K, McVernon J, Brown LE, Jackson DC: Intranasal administration of the TLR2 agonist Pam2Cys provides rapid protection against influenza in mice. Mol Pharm 2012;9:2710-2718.

-16 Roquilly A, Broquet A, Jacqueline C, Gautreau L, Segain JP, de Coppet P, Caillon J, Altare F, Josien R, Asehnoune K: TLR-4 agonist in post-haemorrhage pneumonia: role of dendritic and natural killer cells. Eur Respir J 2013, E-pub ahead of print.

17 Engel AL, Holt GE, Lu H: The pharmacokinetics of Toll-like receptor agonists and the impact on the immune system. Expert Rev Clin Pharmacol 2011;4:275-289.

18 Chan M, Hayashi T, Kuy CS, Gray CS, Wu CC, Corr M, Wrasidlo W, Cottam HB, Carson DA: Synthesis and immunological characterization of toll-like receptor 7 agonistic conjugates. Bioconjug Chem 2009;20:11941200.

19 Wu CC, Hayashi T, Takabayashi K, Sabet M, Smee DF, Guiney DD, Cottam HB, Carson DA: Immunotherapeutic activity of a conjugate of a Toll-like receptor 7 ligand. Proc Natl Acad Sci USA 2007;104:3990-3995.

20 Agassandian M, Mallampalli RK: Surfactant phospholipid metabolism. Biochim Biophys Acta 2013;1831:612-625.

-21 Belz GT, Smith CM, Kleinert L, Reading P, Brooks A, Shortman K, Carbone FR, Heath WR: Distinct migrating and nonmigrating dendritic cell populations are involved in MHC class I-restricted antigen presentation after lung infection with virus. Proc Natl Acad Sci USA 2004;101:8670-8675.

22 Sabet M, Cottam HB, Guiney DG: Modulation of cytokine production and enhancement of cell viability by TLR7 and TLR9 ligands during anthrax infection of macrophages. FEMS Immunol Med Microbiol 2006; 47:369-379.

-23 Datta SK, Sabet M, Nguyen KP, Valdez PA, Gonzalez-Navajas JM, Islam S, Mihajlov I, Fierer J, Insel PA, Webster NJ, Guiney DG, Raz E: Mucosal adjuvant activity of cholera toxin requires Th17 cells and protects against inha- lation anthrax. Proc Natl Acad Sci USA 2010; 107:10638-10643.

24 Julander JG, Bowen RA, Rao JR, Day C, Shafer K, Smee DF, Morrey JD, Chu CK: Treatment of Venezuelan equine encephalitis virus infection with (-)-carbodine. Antiviral Res 2008;80:309-315.

25 Bennett AM, Elvin SJ, Wright AJ, Jones SM, Phillpotts RJ: An immunological profile of $\mathrm{Balb} / \mathrm{c}$ mice protected from airborne challenge following vaccination with a live attenuated Venezuelan equine encephalitis virus vaccine. Vaccine 2000;19:337-347.

26 Smee DF, von Itzstein M, Bhatt B, Tarbet EB: Exacerbation of influenza virus infections in mice by intranasal treatments and implications for evaluation of antiviral drugs. Antimicrob Agents Chemother 2012;56:63286333.

27 Holzinger D, Jorns C, Stertz S, Boisson-Dupuis S, Thimme R, Weidmann M, Casanova JL, Haller O, Kochs G: Induction of MxA gene expression by influenza A virus requires type I or type III interferon signaling. J Virol 2007; 81:7776-7785.

28 Burkhart CG: Reports of immunologic reactions to imiquimod: an assessment of actinic keratoses and treatment concerns in this era of litigation lotto. Dermatol Online J 2005; 11 : 40.

$>29$ Richwald GA: Imiquimod. Drugs Today (Barc) 1999;35:497-511.

30 Hayashi T, Cottam HB, Chan M, Jin G, Tawatao RI, Crain B, Ronacher L, Messer K, Carson DA, Corr M: Mast cell-dependent anorexia and hypothermia induced by mucosal activation of Toll-like receptor 7. Am J Physiol Regul Integr Comp Physiol 2008;295:R123R132.

31 http://www.niaid.nih.gov/topics/ biodefenserelated/biodefense/pages/cata. aspx.

32 Ryzhikov AB, Tkacheva NV, Sergeev AN, Ryabchikova EI: Venezuelan equine encephalitis virus propagation in the olfactory tract of normal and immunized mice. Biomed Sci 1991;2:607-614.

33 Schafer A, Brooke CB, Whitmore AC, Johnston RE: The role of the blood-brain barrier during Venezuelan equine encephalitis virus infection. J Virol 2011;85:10682-10690.

34 Stern PL, van der Burg SH, Hampson IN, Broker TR, Fiander A, Lacey CJ, Kitchener HC, Einstein MH: Therapy of human papillomavirus-related disease. Vaccine 2012;30(suppl 5):F71-F82.

35 Schon MP, Schon M: Imiquimod: mode of action. Br J Dermatol 2007;157(suppl 2):813.

36 Kovach MA, Standiford TJ: Toll like receptors in diseases of the lung. Int Immunopharmacol 2011;11:1399-1406.

37 Schill T, Schon MP, Pletz N, Emmert S, Schon M: Stimulation of pulmonary immune responses by the TLR2/6 agonist MALP-2 and effect on melanoma metastasis to the lung. Exp Dermatol 2012;21:91-98.
Campbell JD, Cho Y, Foster ML, Kanzler H, Kachura MA, Lum JA, Ratcliffe MJ, Sathe A, Leishman AJ, Bahl A, McHale M, Coffman RL, Hessel EM: CpG-containing immunostimulatory DNA sequences elicit TNFalpha-dependent toxicity in rodents but not in humans. J Clin Invest 2009;119:25642576.

39 Beilharz MW, Cummins JM, Bennett AL: Protection from lethal influenza virus challenge by oral type 1 interferon. Biochem Biophys Res Commun 2007;355:740-744.

40 Garcia-Sastre A, Biron CA: Type 1 interferons and the virus-host relationship: a lesson in detente. Science 2006;312:879-882.

41 Haasbach E, Droebner K, Vogel AB, Planz O: Low-dose interferon type I treatment is effective against $\mathrm{H} 5 \mathrm{~N} 1$ and swine-origin $\mathrm{H} 1 \mathrm{~N} 1$ influenza A viruses in vitro and in vivo. J Interferon Cytokine Res 2011;31:515-525.

42 Kugel D, Kochs G, Obojes K, Roth J, Kobinger GP, Kobasa D, Haller O, Staeheli P, von Messling V: Intranasal administration of alpha interferon reduces seasonal influenza A virus morbidity in ferrets. J Virol 2009;83: 3843-3851.

43 Scagnolari C, Trombetti S, Solda A, Selvaggi C, Monteleone K, Spano L, Pierangeli A, Clementi M, Turriziani O, Antonelli G: Pandemic $2009 \mathrm{H} 1 \mathrm{~N} 1$ influenza virus is resistant to the antiviral activity of several interferon alpha subtypes. J Interferon Cytokine Res 2011; 31:475-479.

44 Steel J, Staeheli P, Mubareka S, Garcia-Sastre A, Palese P, Lowen AC: Transmission of pandemic H1N1 influenza virus and impact of prior exposure to seasonal strains or interferon treatment. J Virol 2010;84:21-26.

45 Ioannidis I, Ye F, McNally B, Willette M, Flano E: Toll-like receptor expression and induction of type I and type III interferons in primary airway epithelial cells. J Virol 2013;87: 3261-3270.

46 Goulet ML, Olagnier D, Xu Z, Paz S, Belgnaoui SM, Lafferty EI, Janelle V, Arguello M, Paquet M, Ghneim K, Richards S, Smith A, Wilkinson P, Cameron M, Kalinke U, Qureshi S, Lamarre A, Haddad EK, Sekaly RP, Peri S, Balachandran S, Lin R, Hiscott J: Systems analysis of a RIG-I agonist inducing broad spectrum inhibition of virus infectivity. PloS Pathog 2013;9:e1003298.

47 Tate MD, Ioannidis LJ, Croker B, Brown LE, Brooks AG, Reading PC: The role of neutrophils during mild and severe influenza virus infections of mice. PLoS One 2011; 6:e17618.

48 Walberg K, Baron S, Poast J, Schwartz B, Izotova L, Pestka S, Peterson JW: Interferon protects mice against inhalation anthrax. J Interferon Cytokine Res 2008;28:597-601.

49 Boyaka PN, Tafaro A, Fischer R, Leppla SH, Fujihashi K, McGhee JR: Effective mucosal immunity to anthrax: neutralizing antibodies and Th cell responses following nasal immunization with protective antigen. J Immunol 2003; 170:5636-5643. 
50 Sloat BR, Cui Z: Strong mucosal and systemic immunities induced by nasal immunization with anthrax protective antigen protein incorporated in liposome-protamine-DNA particles. Pharm Res 2006;23: 262-269.

51 Lukaszewski RA, Brooks TJ: Pegylated alpha interferon is an effective treatment for virulent Venezuelan equine encephalitis virus and has profound effects on the host immune response to infection. J Virol 2000;74:50065015.

52 Ryzhikov AB, Ryabchikova EI, Sergeev AN, Tkacheva NV: Spread of Venezuelan equine encephalitis virus in mice olfactory tract. Arch Virol 1995;140:2243-2254.
53 Aronson JF, Grieder FB, Davis NL, Charles PC, Knott T, Brown K, Johnston RE: A single-site mutant and revertants arising in vivo define early steps in the pathogenesis of Venezuelan equine encephalitis virus. Virology 2000;270:111-123.

54 Vogel P, Abplanalp D, Kell W, Ibrahim MS, Downs MB, Pratt WD, Davis KJ: Venezuelan equine encephalitis in Balb/c mice: kinetic analysis of central nervous system infection following aerosol or subcutaneous inoculation. Arch Pathol Lab Med 1996;120:164172.
55 Charles PC, Walters E, Margolis F, Johnston RE: Mechanism of neuroinvasion of Venezuelan equine encephalitis virus in the mouse. Virology 1995;208:662-671.

56 Grieder FB, Davis NL, Aronson JF, Charles PC, Sellon DC, Suzuki K, Johnston RE: Specific restrictions in the progression of Venezuelan equine encephalitis virus-induced disease resulting from single amino acid changes in the glycoproteins. Virology 1995;206:994-1006.

57 Gleiser CA, Gochenour WS Jr, Berge TO, Tigertt WD: The comparative pathology of experimental Venezuelan equine encephalomyelitis infection in different animal hosts. J Infect Dis 1962;110:80-97. 